\title{
MINAT PEMUDA PADA PERTANIAN HORTIKULTURA DI DESA KELOR KECAMATAN KARANGMOJO KABUPATEN GUNUNGKIDUL
}

\author{
Adriana Sharadhea Ningtyas ${ }^{1}$, Bambang Santosa ${ }^{2}$ \\ Program Studi Sosiologi Fakultas Ilmu Sosial dan Politik \\ Universitas Sebelas Maret Surakarta Indonesia \\ Email1: sharadhea@gmail.com,Email²: bambangsantosa56@staff.uns.ac.id
}

\begin{abstract}
Youth is a valuable asset to the country. The success of the nation's development depends on the level of its youth participation. Phenomena declining the interest of youth in agriculture is a special concern for society and government. Amid in the youth interest in the agricultural sector work, there is a group of farmers who have an interest in agriculture, especially horticultural. The purpose of this research is to see the process of increasing youth interest in horticultural farming, a factor that affects youth interest and the process of forming rational youth choices related to increased interest in horticultural farming. Qualitative research with a descriptive exploratory approach was conducted in the village Kelor Karangmojo District in Gunungkidul Regency. Sampling techniques using purposive sampling techniques. As for the research, informant consists of the youths who belong in a group of horticultural farmer Youth, non-village youth groups and village devices. Data is collected by observing, post conducting interviews and documentation. To test the data validity using source triangulation. Data analysis techniques use interactive models of Miles and Huberman with the rational choice theory of James S. Coleman.

The results showed the process of increasing youth interest through: increased youth involvement in horticultural farms that are differentiated into direct involvement and supporting involvement about concerning frequency, long farmed and The youth-owned land area; Increased members of Horticulture Farmer Youth Group; Raising horticultural farmland; and increased youth innovations in horticultural farming. In the factors that affect the interest of the driving factor is the inner urge, social motivation, and emotional factor also the traction factor in the form of economic factors and market availability. The rational choice of youth against horticultural farming occurs because of the objectives that youths want to achieve by doing horticultural farming activities. Youth access to natural resources as well as capital is a tool for youth to get their goals. In maximizing the efforts of youth conduct collective behavior that is by forming a group of agriculture that has access to human resources and capital resources that can overcome the limitations of youth actors of individuals in activities Horticultural farming.
\end{abstract}

Keywords: Youth, Horticultural Farming, Rational Choice

Abstrak: Pemuda merupakan aset negara yang tidak ternilai harganya. Berhasil tidaknya
proses pembangunan bangsa tergantung pada tingkat partisipasi pemudanya. Fenomena
menurunnya minat pemuda dalam pertanian menjadi perhatian khusus bagi masyarakat
maupun pemerintah. Ditengah rendahnya minat pemuda terhadap pekerjaan pada sektor
pertanian, terdapat kelompok pemuda tani yang memiliki minat terhadap bidang pertanian
khususnya hortikultura. Tujuan penelitian ini guna melihat proses peningkatan minat pemuda
pada pertanian hortikultura, faktor yang mempengaruhi minat pemuda dan proses
terbentuknya pilihan rasional pemuda terkait peningkatan minat pertanian hortikultura.
Penelitian kualitatif dengan pendekatan deskriptif eksploratif dilakukan di Desa Kelor
Kecamatan Karangmojo Kabupaten Gunungkidul. Teknik pengambilan sampel dengan 
menggunakan teknik purposive sampling. Adapun informan penelitian terdiri dari pemuda yang tergabung dalam kelompok pemuda tani hortikultura, pemuda desa non-kelompok dan perangkat desa. Data dikumpulkan dengan melakukan observasi, wawancara mendalamdan dokumentasi. Untuk menguji validitas data menggunakan triangulasi sumber. Teknik analisis data menggunakan model interaktif Miles dan Huberman dengan teori Pilihan Rasional dari James S. Coleman.

Hasil penelitian menunjukkan proses peningkatan minat pemuda melalui: peningkatan keterlibatan pemuda dalam pertanian hortikultura yang dibedakan menjadi keterlibatan langsung dan keterlibatan penunjang dengan memperhatikan frekuensi, lama bertani dan luasan lahan yang dimiliki pemuda; peningkatan anggota kelompok pemuda tani hortikultura; peningkatan lahan pertanian hortikultura; dan peningkatan inovasi pemuda pada pertanian hortikultura. Pada faktor yang mempengaruhi minat terdapat faktor pendorong yaitu inner urge, social motivation dan emotional factor juga faktor penarik berupa faktor ekonomis dan ketersediaan pasar. Pilihan rasional pemuda terhadap pertanian hortikultura terjadi karena adanya tujuan-tujuan yang ingin diraih pemuda dengan melakukan kegiatan pertanian hortikultura. Akses pemuda terhadap sumber daya alam maupun modal menjadi alat bagi pemuda untuk mendapatkan tujuannya. Dalam memaksimalkan usahanya pemuda melakukan perilaku kolektif yaitu dengan membentuk kelompok pertanian yang memiliki akses terhadap sumber daya manusia dan sumber daya modal yang mampu mengatasi keterbatasan pemuda sekalu aktor individu dalam kegiatan pertanian hortikultura.

Kata Kunci: Pemuda, Pertanian Hortikultura, Pilihan Rasional

\section{PENDAHULUAN}

Indonesia telah lama dikenal sebagai Negara agraris yang dikanal dengan kekayaan hasil alam, keragaman hayati, iklim tropis yang mendukung sektor pertanian. Dalam pertanian Mosher menyatakan bahwa manusia memiliki andil untuk turut serta dalam perkembangan tanaman dan atau hewan, agar dapat memenuhi kebutuhan masyarakat (Mardikanto, 2007). Sebagai sektor penting di Indonesia pembangunan pertanian memerlukan perhatian khusus sebagai bentuk pengoptimalan sumber daya alam dan sumber daya manusia yang terlibat pada sektor pertanian secara berkelanjutan. Sektor pertanian yang berkembang di Indonesia secara umum meliputi subsektor tanaman pangan, hortikultura, perkebunan, peternakan, kehutanan dan perikanan (Prastowo dan Sardjono, 2007).

Permasalahan mengenai kebijakan, organisasi pertanian yang tidak berfungsi dengan baik, kepemilikan lahan, teknologi informasi, tata niaga hingga modal mewarnai kehidupan pertanian di Indonesia dan semakin memburuk dengan permasalahan mengenai rendahnya minat pemuda terhadap pertanian yang menyebabkan rendahnya regenerasi petani (Aprianto, 2012). Data Badan Pusat Statistik (BPS) menunjukkan bahwa terjadi penurunan jumlah petani di Indonesia tercatat sejak tahun 2010 hingga 2017 terjadi penurunan setiap tahunnya sejumlah 1,1\%. Pada tahun 2010 petani di Indonesia berjumlah 42,8 juta jiwa dan pada tahun 2017 menjadi 39,7 juta jiwa dan terus mengalami penurunan terhitung pada Februari 2017 hingga Februari 2018 tercatat terjadi penurunan jumlah petani sebesar 1,41\%. Laju modernisasi dan urbanisasi menyebabkan kemajuan pada sebagian besar penduduk pedesaan yang kemudian membentuk presepsi di kalangan masyarakat yang menganggap pekerjaan di bidang pertanian tidak lagi menarik sehingga banyak dari masyarakat terutama pemuda meninggalkan sektor pertanian dan beralih pada pekerjaan diluar sektor pertanian. Sedangkan White (2012) mengemukakan pandangan berbeda terhadap rendahnya minat pemuda pada sektor pertanian melalui 3 (tiga) faktor diantaranya: sistem pendidikan di Indonesia yang 
menanamkan ide bahwa pekerjaan di sektor pertanian bukan hal yang menarik; pemerintah yang tidak memperhatikan pertanian skala kecil; dan terbatasnya akses pemuda terhadap lahan.

Minat merupakan rasa suka dan ketertarikan terhadap suatu hal tanpa adanya sebuah paksaan. Minat pada dasarnya merupakan penerimaan terhadap hubungan antara diri sendiri dengan sesuatu di luar diri (Djaali, 2008). Minat menurut Crow \& Crow dalam Z. Kasijan (1984:4) dibagi menjadi 3 (tiga) faktor yaitu: (1) inner urge, dorongan dari dalam diri manusia yang berhubungan dengan jasmani maupun psikis; (2) social motivation, dorongan yang timbul akibat adanya motivasi sosial; (3) emotional factor, dorongan yang timbul akibat adanya perjalanan sukses yang dialami oleh seseorang ataupun orang lain. Sedangkan pemuda merupakan periode transisi dari masa kanak-kanak menuju masa dewasa yang memiliki sifat mandiri dan sadar akan kemandiriannya sebagai bagian dari masyarakat (Mukhlis, 2007).

Rendahnya minat pemuda terhadap pertanian menyebabkan sektor ini di dominasi oleh petani tua dengan produktivitas yang menurun. Menurut data BPS Daerah Istimewa Yogyakarta penurunan produktifitas hasil pertanian terjadi di Daerah Istimewa Yogyakarta pada tahun 2017 menurun sejumlah 0,23\% dari tahun sebelumnya. Masalah rendahnya minat pemuda terhadap pertanian menjadi perhatian pemerintah Daerah Istimewa Yogyakarta untuk merancang rumusan aksi yang tertuang dalam Laporan Kinerja Instansi Pemerintah Dinas Pertanian DIY untuk mengembangkan minat generasi muda untuk bekerja di sektor pertanian melalui penumbuhan wirausahawan muda pertanian, pemberian modal dan pelatihan khusus pertanian atau agribisnis bagi generasi muda. Ditengah banyaknya isu mengenai penurunan minat pemuda pada pertanian terdapat sekelompok pemuda di Desa Kelor Kecamatan Karangmojo Kabupaten Gunungkidul yang mulai mengalami peningkatan minat dalam sektor pertanian khususnya pertanian hortikultura. Berdasarkan uraian diatas, mendorong peneliti untuk untuk melakukan penelitian secara mendalam mengenai proses peningkatan minat pemuda pada pertanian hortikultura, faktor peningkatan minat pemuda dan proses terbentuknya pilihan rasional pemuda terkait peningkatan minat terhadap pertanian hortikultura. Penelitian ini dilakukan pada pemuda Desa Kelor Kecamatan Karangmojo Kabupaten Gunungkidul.

\section{METODE}

Penelitian ini dilakukan di Desa Kelor, Kecamatan Karangmojo, Kabupaten Gunungkidul, dikarenakan progresifitas minat pemuda pada pertanian hortikultura di Desa Kelor cenderung positif. Secara spesifik penelitian ini dilakukan pada Kelompok Pemuda Tani Hortikultura "Mudo Mulyo Dadi". Penelitian ini merupakan penelitian deskriptif kualitatif dengan pendekatan eksploratif. Teknik pengambilan sample yang digunakan adalah purposive sampling, agar sample yang diambil benar-benar representatif serta memahami secara pasti mengenai data yang dibutuhkan untuk penelitian ini. Maka dari itu informan penelitian terdiri dari pendiri kelompok pemuda tani hortikultura "Mudo Mulyo Dadi", ketua kelompok Mudo Mulyo Dadi, anggota kelompok Mudo Mulyo Dadi, pemuda desa nonkelompok dan perangkat Desa Kelor. Data dikumpulkan melalui observasi kegiatan pertanian pemuda Desa Kelor dan kegiatan diskusi kelompok Mudo Mulyo Dadi, serta melalui wawancara mendalam dengan seluruh informan dan mengkaji dokumen terkait minat pemuda pada pertanian hortikultura. Untuk menguji validitas data dilakukan triangulasi sumber dengan membandingkan jawaban informan lain dalam melakukan cross check data yang diperoleh langsung, sehingga antara data yang satu terkontrol oleh data yang lain. 


\section{PEMBAHASAN}

\section{Proses Peningkatan Minat Pemuda Pada Pertanian Hortikultura}

a) Peningkatan Keterlibatan Pemuda

Penurunan jumlah petani di Indonesai terjadi seiring dengan pergeseran dari masyarakat agraris menjadi masyarakat non agraris. Keterlibatan pemuda pada sektor pertanian diharapkan mampu memperbaiki fenomena rendahnya minat pemuda pada sektor pertanian menyebabkan penurunan keterlibatan (departisipasi). Berdasarkan penelitian Untari et al. (2007) akses informasi mempengaruhi keterlibatan pemuda dalam pertanian. Semakin tinggi akses pemuda terhadap informasi pertanian, maka akan semakin besar pengaruhnya terhadap keterlibatan pemuda pada pertanian di pedesaan. Pendapat lain dikemukakan oleh Nugraha (2012) yang menyatakan bahwa keterlibatan pemuda dalam pertanian tergantung pada akses lahan keluarga.

Keterlibatan pemuda dalam pertanian hortikultura di Desa Kelor tidak hanya merujuk pada pemuda yang tergabung dalam kelompok pemuda tani hortikultura "Mudo Mulyo Dadi" namun juga pada keterlibatan pemuda Desa Kelor non-kelompok dan pemuda luar desa (eksternal). Keterlibatan pemuda Desa Kelor pada pertanian hortikultura terbagi menjadi 2 jenis yaitu keterlibatan langsung dan keterlibatan penunjang. Keterlibatan langsung dalam pertanian hortikultura di Desa Kelor mencakup serangkaian kegiatan pertanian diantaranya: persiapan lahan, penyemaian benih, penanaman, pemupukan, penyiangan gulma, pembasmian hama, pengairan dan panen. Pada keterlibatan langsung pertanian hortikultura, partisipasi kelompok pemuda tani hortikultura "Mudo Mulyo Dadi" lebih aktif dibandingkan dengan pemuda non-kelompok yang melakukan serangakain kegiatan pertanian yang tidak lengkap karena keterlibatan langsung pemuda desa non-kelompok masih pada saat penanaman dan masa panen dan mengabaikan serangakaian tahapan pertanian lainnya. Sedangkan pada pemuda luar desa (eksternal) belum melakukan serangkaian kegiatan pertanian secara langsung sehingga dapat dikatakan pemuda luar desa (eksternal) pasif dalam keterlibatan langsung pada pertanian hortikultura di Desa Kelor.

Keterlibatan penunjang merupakan keterlibatan pemuda secara tidak langsung pada kegiatan pertanian. Keterlibatan ini meliputi akses informasi pemuda terhadap pertanian hortikultura. akses pemuda Desa Kelor terhadap informasi pertanian ditunjang dengan penyelenggaraan perpustakaan desa yang mendukung informasi terhadap dunia pertanian khususnya hortikultura melalui buku-buku. Keterampilan pemuda dalam berselancar di jejaring internet maupun media sosial untuk mengakses informasi mengenai pertanian hortikultura. Dilengkapi dengan informasi yang diberikan oleh pemerintah melalui sosialisasi maupun penyuluhan mengenai kegiatan pertanian hortikultura. Pada kelompok pemuda tani hortikultura Mudo Mulyo Dadi keterlibatan penunjang diatas dilengkapi dengan akses informasi melalui diskusi internal, sharing dengan petani lainnya dan talk show nasional yang diikuti oleh anggota kelompok tani. Pada pemuda desa non-kelompok kegiatan penunjang yang diikuti berupa sosialisasi pertanian oleh pemerintah, keterampilan berselancar di jejaring internet untuk mengakses informasi mengenai pertanian hortikultura dan diskusi bersama anggota kelompok pemuda tani hortikultura Mudo Mulyo Dadi. Sedangkan pada pemuda luar desa (eksternal) kegiatan penunjang yang dilakukan dalam keterlibatannya pada pertanian hortikultura di Desa Kelor berupa pendampingan berkala. Kegiatan pendampingan berkala ini merupakan bentuk kerjasama pemuda dengan mahasiswa dalam mengembangkan produktifitas pertanian hortikultura di Desa Kelor.

Akses pemuda terhadap lahan merupakan bagian penting dari keterlibatan pemuda dalam pertanian. Penguasaan lahan merupakan nyawa bagi petani, terbatasnya lahan yang dimiliki oleh petani mengakibatkan kerentanan dalam kehidupan petani (Wiradi, 2009). 
Penguasaan lahan yang dimiliki oleh kelompok pemuda tani Mudo Mulyo Dadi berkisar > 0,5 Ha, pada pemuda Desa non-kelompok dan pemuda luar desa (eksternal) penguasaan lahan berkisar < 0,5 Ha, hal ini dikarenakan pemuda non-kelompok dan pemuda luar desa (eksternal) belum melakukan kegiatan pertanian sebagai mata pencaharian utama.

Keterlibatan yang tinggi oleh pemuda dalam bertani diukur dari lama pemuda melakukan kegiatan pertanian lebih dari 4 (empat) dengan frekuensi bertani dalam satu minggu lebih dari 3 (tiga) kali (Istiqomah, 2017). Keterlibatan pemuda yang tergabung dalam kelompok pemuda tani Mudo Mulyo Dadi dapat dikategorikan sebagai keterlibatan tinggi dengan melihat frekuensi bertani dalam satu minggu mencapai 3 (tiga) hingga 7 (tujuh) kali. Sedangkan pada pemuda desa non-kelompok dapat dikategorikan sebagai keterlibatan sedang dengan frekuensi bertani dalam satu minggu 0 (nol) hingga 3 (tiga) hari dan lama bertani kurang dari 3 tahun. Sedangkan pada pemuda luar desa (eksternal) dapat dikategorikan sebagai keterlibatan rendah dengan frekuensi bertani 0 (nol) hari dalam satu minggu dan lama bertani kurang dari 1 tahun.

b) Peningkatan Anggota Kelompok Pemuda Tani Hortikultura

Dalam Peraturan Menteri Pertanian Republik Indonesia Nomor 67/Permentan/Sm.050/12/2016 Tentang Pembinaan Kelembagaan Petani, Bab II Pasal Kelompok Tani disebutkan jumlah anggota kelompok tani berkisar 20 hingga 30 orang petani atau dapat disesuaikan dengan kondisi lingkungan masyarakat dan usahataninya. Jumlah pemuda dalam kelompok pemuda tani hortikultura Mudo Mulyo Dadi dapat terbilang efektif sesuai dengan yang tertuang pada Peraturan Menteri Pertanian.

Meskipun kelompok tani merupakan wadah bagi pemuda yang berminat dalam sektor pertanian hortikultura, namun untuk menjadi anggota kelompok pemuda diharuskan untuk mengikuti sejumlah aturan yang tertuang dalam Anggaran Dasar dan Anggaran Rumah Tangga (AD/ART) dari kelompok pemuda tani hortikultura Mudo Mulyo Dadi. Adanya AD/ART dimaksudkan untuk menciptakan kondusifitas dalam kelompok pemuda tani hortikultura Mudo Mulyo Dadi dengan merumuskan aturan yang menjadi pedoman pemuda dalam melakukan kegiatan berkelompok. Meskipun terdapat aturan yang mengatur mengenai anggota baru, tidak menutup minat pemuda Desa Kelor untuk tergabung dalam kelompok pemuda tani hortikultura Mudo Mulyo Dadi, terbukti dengan terus beratambahnya anggota kelompok setiap tahunnya. Tercatat pada tahun 2015 jumlah anggota kelompok pemuda tani hotikultura Mudo Mulyo Dadi hanya berjumlah 3 (tiga) dan bertambah menjadi 12 (dua belas) orang anggota pada tahun 2016 dan pada tahun 2018 bertambah menjadi 22 (dua puluh dua) orang anggota. Peningkatan jumlah anggota kelompok pemuda tani hortikultura menandakan bahwa minat pemuda dalam pertanian hortikultura di Desa Kelor terus mengalami peningkatan.

\section{c) Peningkatan Lahan Pertanian Hortikultura}

Kebutuhan lahan yang semakin meningkat mengakibatkan semakin langkanya lahan pertanian yang mendukung budidaya pertanian yang unggul sehingga memerlukan optimalisasi penggunaan sumberdaya lahan yang memungkinkan tetap tersedianya lahan untuk pertanian secara berkelanjutan. Tantangan ini merupakan salah satu masalah dan tantangan serius dalam pertanian di Indonesia (Ahmadi dan Irsal Las, 2006). Ketersedian lahan untuk pertanian hortikultura sampai saat ini masih sangat kecil jika dibandingkan dengan lahan pertanian lainnya. Jika dilihat dari potensi kedepannya bahwa produk-produk hortikultura sangatlah menjanjikan untuk dikembangkan maka perlu dilakukan 
pengembangan hortikultura. Pengembangan hortikultura dapat dilakukan dengan pemanfaatan ketersediaan lahan. (Renstra Dirjen Hortikultura 2015-2019).

Salah satu indikator peningkatan minat pemuda Desa Kelor dalam pertanian hortikultura ditandai dengan meningkatnya lahan garapan. Adanya peningkatan lahan pertanian hortikultura diantaranya disebabkan adanya pergeseran lahan pertanian tradisional (padi dan palawija) yang diubah menjadi lahan pertanian hortikultura. Meskipun tidak mengalami perluasan yang signifikan adanya peningkatan lahan pertanian hortikultura cukup menjadi ciri-ciri meningkatnya minat pemuda terhadap pertanian hortikultura di desa kelor. Total luas lahan anggota kelompok pemuda tani Mudo Mulyo Dadi berkisar kurang lebih 10 hektar dengan lokasi yang terpisah. Perluasan lahan pertanian hortikultura tidak hanya terjadi pada lahan garapan, sebagian pemuda yang memiliki minat pada sektor pertanian hortikultura namun masih belum memiliki akses terhadap lahan pertanian, memilih untuk mengembangkan pertanian hortikultura dengan skala yang lebih kecil yaitu skala rumah tangga. Selain itu pemuda memanfaatkan lahan tidur atau lahan yang sedang tidak ditanami untuk kemudian dipinjam ataupun disewa untuk ditanami tanaman hortikultura.

\section{d) Peningkatan Inovasi Pertanian}

Inovasi pertanian berperan penting dan sangat dibutuhkan oleh petani sebagai alat untuk meningkatkan produktifitas. Simamora (2003) dalam Musyafak dan Tatang Ibrahim (2005) menyatakan bahwa inovasi adalah suatu ide, praktek atau produk yang dianggap baru oleh individu atau grup yang relevan. Oleh karena itu pengertian inovasi tidak sebatas benda atau barang hasil produksi saja tetapi mencakup ideologi, kepercayaan, sikap hidup, informasi, perilaku atau gerakan-gerakan menuju proses perubahan dalam kehidupan masyarakat. Sehingga dengan adanya inovasi pada sektor pertanian, petani berpeluang untuk meningkatkan kesejahteraan hidup, yang salah satunya diindikasikan dari meningkatnya ketahanan pangan rumah tangga petani. Inovasi dalam sektor pertanian menjadi ciri lain meningkatnya minat pemuda pada sektor pertanian di Desa Kelor.

Sistem pertanian hortikultura merupaka inovasi pertanian pertama yang dilakukan oleh pemuda Desa Kelor, adanya perubahan dari sistem pertanian konvensional padi dan palawija menjadi sistem pertanian hortikultura yang memberikan sebuah perubahan besar pada pemuda Desa Kelor khususnya pada anggota kelompok pemuda tani Mudo Mulyo Dadi dalam memandang pekerjaan di sektor pertanian. Seiring dengan meningkatnya minat pemuda desa pada sektor pertanian hortikultura, pengembangan inovasi-inovasi terus berkembang.

Inovasi yang sedang dikembangkan oleh kelompok pemuda tani Mudo Mulyo dadi diantaranya: inovasi penanaman dengan pemaksimalan pertumbuhan tanaman; pengadaan tanaman cadangan, sebagai bentuk antisipasi harga pasar yang fluktuatif terhadap produk tanaman pokok; pengadaan bibit mandiri dari hasil panen; dan kerjasama pengembangan bersama pihak eksternal. Selain inovasi yang dikembangkan sendiri oleh pemuda Desa Kelor, pemuda yang tergabung dalam kelompok pemuda tani hortikultura juga menerapkan inovasiinovasi yang diadakan oleh pemerintah, seperti inovasi teknologi dalam penggarapan lahan dengan menggunakan mesin pertanian untuk mengolah tanah sekunder (cultivator) dan pengadaan mesin pemubuat tepung cabai sebagai upaya pengelolaan produk pasca panen.

\section{Faktor Peningkatan Minat Pemuda Pada Pertanian Hortikultura}

a) Faktor Pendorong Minat

Pekerjaan di bidang pertanian perlu diawali dengan adanya minat dalam diri seseorang. Menurut Suhartini (2011) minat tidak timbul dengan sendirinya, akan tetapi 
minat akan tumbuh dan berkembang sesuai dengan faktor-faktor yang mempengaruhinya, baik faktor sosial maupun faktor ekonomi. Faktor sosial timbul karena adanya pengaruh dari luar seperti lingkungan keluarga, lingkungan masyarakat dan status sosial. Sejalan dengan pernyataan Suhartini menurut Crow dalam (Crow, 1973) yang mengklasifikasikan faktorfaktor yang mempengaruhi minat yaitu: Faktor dorongan (inner urge) yang berasal dari dalam diri individu, kebutuhan ini dapat berupa kebutuhan yang berhubungan dengan jasmani dan kejiwaan; faktor motif sosial (social motivation) minat yang timbul karena faktor ini disebabkan oleh adanya dorongan motif sosial yang berupa kebutuhan untuk meningkatkan status sosial di masyarakat; faktor emosional, dalam faktor ini perasaan dan emosi memiliki pengaruh terhadap obyek misalnya perjalanan sukses yang dipakai individu dalam suatu kegiatan tertentu dapat pula membangkitkan perasaan senang dan dapat menambah semangat atau kuatnya minat dalam kegiatan tersebut.

Dari hasil identifikasi peningkatan minat pemuda desa terhadap pertanianan hortikultura di desa kelor, faktor-faktor pendorong peningkatan minat diantaranya meliputi Inner Urge (dorongan dari dalam), Social Motivation (motif sosial) dan Emotional Factor (faktor emosional). Faktor inner urge merupakan bentuk rangsangan dari dalam atau pembawaan pemuda Desa Kelor yang sesuai dengan keinginan dan ketertarikan yang kemudian menimbulkan minat untuk bekerja pada sektor pertanian hortikultura. Rangsangan dari dalam memberikan dorongan pada pemuda Desa Kelor untuk memberikan perhatian lebih dan rasa keingintahuan mengenai kegiatan pertanian khususnya pertanian hortikultura. Rangsangan dari dalam pemuda Desa Kelor menimbulkan sebuah usaha yang konkret sebagai bentuk tindak lanjut terhadap minat yang timbul. Adanya keinginan untuk melakukan kegiatan berbeda dan lebih positif menjadi alasan bagi pemuda Desa Kelor untuk mengembangkan minat di bidang pertanian hortikultura. Pemuda Desa Kelor sebelum memiliki minat terhadap kegiatan pertanian hortikultura mayoritas bekerja di sektor lain salah satunya adalah pekerja bangunan. Mayoritas pemuda setelah pulang bekerja melakukan kegiatan kurang positif dengan bermabuk- mabukan. Sehingga beberapa dari pemuda sadar untuk mulai mengubah pola berfikir dan mencari kegiatan yang berbeda dan lebih positif melalui kegiatan pertanian hortikultura.

Indikator lainnya dari munculnya minat melalui inner urge adalah adanya rasa ingin tahu untuk menciptakan kegiatan pertanian yang berbeda. Pertanian di Desa Kelor sebelum munculnya kelompok tani hortikultura Mudo Mulyo Dadi didominasi oleh pertanian padi dan palawija dan sebagian besar dikerjakan oleh orang tua dan minimnya pemuda yang meminati kegiatan bertani padi dan palawija. Munculnya keinginan untuk menciptakan kondisi pertanian yang berbeda sejak tahun 2015 dengan diawali oleh Sujito dengan melakukan eksperimen menanam cabai sebagai langkah awal wujud kepeminatannya terhadap pertanian dan rasa keingintahuannya mencoba kegiatan pertanian jenis lainnya yang berbeda dengan pertanian yang sudah ada sebelumnya di Desa Kelor. Selain itu dorongan dari dalam yang tercipta dari keadaan yang dialami pemuda Desa Kelor yaitu faktor ekonomi, tidak dipungkiri bahwa sektor pertanian hortikultura cukup membantu para anggota kelompok tani hortikultura dalam perekonomian. Sehingga faktor kebutuhan ekonomi menjadi salah satu landasan pemuda Desa Kelor berminat bekerja pada sektor pertanian hortikultura.

Minat menunjukkan kecenderungan ingin mengetahui sesuatu secara lebih mendalam. Minat juga merupakan suatu keadaan dimana seseorang menaruh perhatian kepada sesuatu disertai keinginan untuk mengetahui, mempelajari atau membuktikan lebih lanjut. Adanya rasa ingin tahu dan menciptakan kegiatan pertanian yang berbeda inilah menjadi salah satu pemicu adanya pengingkatan minat pemuda Desa Kelor di bidang pertanian hortikultura yang kemudian diwujudkan dengan mempelajarai dan mencari tahu lebih lanjut mengenai 
pertanian hortikultura hingga terbentuknya sebuah aksi kegiatan pertanian langsung yang dilakukan oleh beberapa pemuda desa sebagai wujud nyata dari tingginya minat pemuda Desa Kelor terhadap pertanian hortikultura yang merupakan kegiatan pertanian yang sebelumnya belum diterapakan oleh petani-petani tua (Walgito, 1991).

Selain dipengaruhi faktor dari dorongan dari dalam, minat seorang individu dipengaruhi oleh faktor social motivation (motif sosial) untuk merubah presepsi masyarakat tentang pekerjaan di sektor pertanian. Pada peningkatan minat pemuda Desa Kelor motif sosial timbul sebagai bentuk keinginan pemuda mengubah presepsi petani tua terhadap petani muda dan pandangan masyarakat terhadap kelompok tani Mudo Mulyo Dadi yang sebagian besar didominasi oleh pemuda dengan image suka bermabuk-mabukan. Social motivation atau motif sosial diartikan sebagai dorongan yang membangkitkan minat dalam diri dengan tujuan untuk mendapatkan pengakuan ataupun penghargaan.

Pada emotional factor (faktor emosi) dalam penelitian ini dilihat sebagai salah satu faktor yang meningkatkan minat pemuda Desa Kelor terhadap sektor pertanian hortikultura melalui adanya perjalanan sukses yang dialami oleh pemuda Desa Kelor dalam melakukan kegiatan pertanian hortikultura. Peningkatan minat melalui faktor emosi ini dilihat dari cari seorang individu memandang kesuksesan orang yang kemudain membangkitkan minatnya terhadap sektor pertanian hortikultura maupun pengalaman kesuksesan seorang individu itu sendiri dalam melakukan kegiatan pertanian hortikultura.

\section{b) Faktor Penarik Minat}

Selain faktor pendorong minat yang berasal dari dalam diri pemuda maupun lingkungan sekitarnya, terdapat pula faktor penarik minat pemuda yang berasal dari potensi pemasaran komoditas hortikultura dari Desa Kelor dengan varietas unggulan berupa cabai merah dan bawang merah. Faktor penarik tersebut diantaranya: Faktor Ekonomis dan Ketersediaan Pasar. Permentan No. 76/Permentan/OT.140/12/2012 menyebutkan tentang Syarat dan Tatacara Penetapan Produk Unggulan Hortikultura dan mengacu pada Permentan No. 50/Permentan/OT.140/8/2012 tentang Pedoman Pengembangan Kawasan Pertanian dan Kementan No. 45/Kpts/PD.200/1/2015 tentang Penetapan Kawasan Cabai, Bawang Merah, dan Jeruk Nasional. Adapun komoditas hortikultura yang akan secara intensif mendapat perhatian utama pada level nasional pada periode 2015 - 2019 adalah: aneka cabai, bawang merah, jeruk.

Cabai yang merupakan komoditas hortikultura yang sangat dibutuhkan masyarakat dan merupakan salah satu penyebab inflasi secara nasional. Cabai juga merupakan produk hasil pertanian unggulan pemuda tani hortikultura di Desa Kelor yang memiliki harga jual yang cukup baik meskipun seringkali terjadi ketidakstabilan harga pasar. Harga komoditas pertanian hortikultura berbeda-beda berdasarkan jenisnya. Untuk cabe, harga ditentukan oleh harga pasar yang berlaku saat itu. Pemuda tani hortikultura Mudo Mulyo Dadi memiliki akses yang cukup luas untuk mendapatkan informasi harga cabai. Informasi tersebut biasanya dilakukan melalui survey pasar oleh anggota kelompok pemuda tani Mudo Mulyo Dadi dan melalui kontak telepon dengan pedagang maupun pengepul. Pada musim panen raya (suplai banyak), harga cabe rawit ditingkat petani berkisar Rp.8,000 per kilogram sedangkan pada suplai sedikit, harga cabe tingkat petani mencapai Rp. 29,000,- per kilogram.

Dalam pertanian hortikultura ada beberapa kekhasan yang dimiliki antara lain (1) usahatani yang dilakukan lebih berorientasi pasar (tidak konsisten), (2) bersifat padat modal, (3) risiko harga relatif besar karena sifat komoditas yang cepat rusak dan (4) dalam jangka pendek harga relatif berfluktuasi (Hadi et al, 2000; Irawan, 2001). Keuntungan, durasi tanam yang pendek serta sesuai dengan permintaan pasar menjadi alasan pemuda Desa Kelor 
memilih beralih ke pertanian hortikultura. Penjualan hasil pertanian hortikultura dilakukan petani langsung setelah panen kepada pengumpul maupun ke pasar. Dapat dikatakan bahwa pertanian hortikultura terutama komoditas cabai ini sangat menguntungkan untuk diusahakan. Apalagi bila petani bisa mendapatkan harga tinggi disaat panen diluar musim (off season) ataupun ketika suplai cabai di pasaran sedikit. Pemuda tani mendapatkan harga diatas 20 ribu rupiah per kilogramnya. Tidak hanya komoditas unggulan yang mendapatkan keuntungan yang cukup besar, komoditas lain yang ditanam oleh pemuda tani Mudo Mulyo Dadi seperti timun juga mendapatkan harga pasar yang cukup baik. Hal ini menjadi faktor penarik bagi pemuda Desa Kelor untuk menekuni pertanian hortikultura.

Ketersediaan pasar merupakan faktor penting yang perlu diperhatikan dalam sektor pertanian. Diperlukan dukungan iklim usaha dan kondisi pasar yang kondusif baik di domestik maupun global. Salah satunya memang faktor ketersediaan pasar, sehingga perlu kombinasi tujuan pasar untuk dalam negeri dan ekspor. Jika pasar optimal, maka produksi dapat maksimal. Komoditas hortikultura yang dikembangkan pemuda tani Mudo Mulyo Dadi merupakan komoditas yang cukup penting bagi masyarakat diantaranya cabai dan bawang merah, ketersediaan pasar yang dapat menampung hasil panen pemuda tani Mudo Mulyo Dadi menjadi salah satu faktor penting pasca panen. Dalam hal ini pemuda tani Mudo Mulyo Dadi menjual hasil panen ke pengepul atau langsung menjualnya ke pasar di Gunungkidul maupun di D.I Yogyakarta. Jika menjual ke pengumpul lokal, pengumpul datang ke lahan pertanian pemuda dan transaksi dilakukan di lahan. Sedangkan penjualan langsung ke pasar biasanya dilakukan bersama (kolektif) dengan mengumpulkan hasil panen anggota kelompok pemuda atani Mudo Mulyo Dadi kemudian dibawa ke pasar yang dituju. Ketersediaan pasar yang jelas dan beragam menjadi faktor penarik tersendiri bagi pemuda Desa Kelor pada sektor pertanian hortikultura. Karena tersedianya pasar yang jelas dan dapat sewaktu-waktu menampung hasil panen sehingga meminimalisir hasil panen yang tidak terjual ataupun membusuk akibat terlalu lama tersimpan. Sektor pertanian hortikultura yang dikembangkan pemuda tani Mudo Mulyo Dadi merupakan komoditas yang penting dalam rumah tangga sehingga meskipun terdapat hasil panen yang tersisa maka masih bisa dimanfaatkan untuk kebutuhan rumah tangga pemuda tani Mudo Mulyo Dadi.

\section{Proses Terbentuknya Pilihan Rasional Pemuda Terkait Peningkatan Minat Terhadap Pertanian Hortikultura}

Coleman dengan teori pilihan rasionalnya menjelaskan bahwa seseorang melakukan tindakan dengan memanfaatkan suatu barang atau sumber daya untuk memenuhi tujuannya. Dalam teori pilihan rasional ada 2 unsur penting yaitu aktor dan sumber daya. Aktor yang dimaksud disini adalah pemuda tani sedangkan sumber daya adalah lahan pertanian yang mereka miliki (Ritzer dan Goodman, 2008:394). Selain itu terdapat aktor kolektif yang muncul akibat adanya prilaku kolektif dimana aktor membutuhkan tempat untuk menyandarkan tujuannya agar dapat tercapai dengan cepat. Aktor kolektif dalam penelitian ini merupakan kelompok pemuda tani hortikultura "Mudo Mulyo Dadi".

Menurut Coleman dalam teori pilihan individu tersebut membuat sebuah tindakan atau pilihan untuk memenuhi sebuah tujuan yang ingin dia capai. Tujuan tersebut bisa tercapai dengan menggunakan sumber daya yang dia miliki dan memaksimalkan kegunaan dari sumber daya tersebut. Rasionalitas sendiri menurut Coleman antara individu yang satu dengan individu yang lain itu tidak sama karena dipengaruhi oleh cara memandang suatu permasalahan yang berbeda. Rasional menurut seseorang dan tidak rasional menurut orang lain. Semua itu seharusnya dikembalikan kepada pelaku tersebut jangan mengukurnya dari sudut pandang orang lain (Coleman, 2011:21). Teori Pilihan Rasional Coleman menekankan 
bahwa seorang individu melakukan sebuah tindakan yang mana tindakan tersebut akan memanfaatkan sumber daya yang dia miliki untuk mencapai sebuah tujuan. Artinya, tindakan seseorang itu merupakan tindakan purposif atau bertujuan. Ada 2 hal penting dalam teori pilihan rasional Coleman yang pertama adalah aktor dan yang kedua adalah sumber daya. Sumber daya merupakan adalah suatu barang atau benda yang akan digunakan oleh aktor tersebut untuk mendukung tindakannya dalam mencapai sebuah tujuan. Sumber daya yang dimaksud tidak hanya sumber daya alam melainkan juga sumber daya manusia dan sumber daya modal yang berupa teknologi dan informasi yang kemudian dijadikan alat oleh aktor untuk mencapai tujuannya (Coleman, 2011:21).

Pemuda Desa Kelor dalam hal ini bertindak sebagai aktor individual yang didalam dirinya memiliki tujuan atau latar belakang tertentu untuk memutuskan melakukan kegiatan pertanian, khususnya pertanian hortikultura. Tujuan-tujuan dari pemuda dalam proses peningkatan minat terhadap pertanian hortikultura beragam, diantaranya bertujuan untuk melakukan kegiatan yang lebih positif, memenuhi kebutuhan keluarga dan meningkatkan taraf hidup. Aktor individual dalam merasionalisasikan tujuannya, memilih untuk melakukan kegiatan pertanian hortikultura dengan menggunakan akses yang dimiliki terhadap sumber daya, berupa sumber daya lahan yang dimiliki pribadi ataupun sewa. Selain itu juga dengan menggunakan akses terhadap sumber daya modal yang berupa informasi. Akses terhadap informasi pada aktor individual dilakukan dengan kegiatan akses informasi melalui perpustakaan desa maupun akses informasi melalui gawai dan informasi langsung berupa penyuluhan, sosialisasi, diskusi dan sharing.

Petani sebagai aktor dan sumber daya yang mana petani memiliki kuasa dan kepentingan. Jadi, hubungan diantara keduanya adalah kuasa dan kepentingan (Coleman, 2011:37). Sumber daya merupakan alat yang digunakan pemuda untuk mendapatkan kepentingan ataupun tujuan yang ingin diraih. Aktor memiliki sumber yang berbeda maupun akses yang berbeda terhadap sumberdaya yang lain. Semakin besar akses terhadap sumberdaya yang dimiliki aktor maka semakin besar pula kesempatan untuk meraih tujuan yang diinginkan. Sebaliknya jika sumberdaya yang dimiliki aktor cenderung sedikit maka kesempatan untuk meraih tujuan akan lebih sulit.

Keterbatasan pemuda Desa Kelor terhadap aksesnya pada sumberdaya lahan, mengakibatkan terbentuknya prilaku kolektif, menurut teoi pilihan rasional prilaku kolektif timbul akibat adanya upaya untuk aktor untuk memaksimalkan kepentingan mereka. Dengan adanya upaya untuk memaksimalkan kepentingan individual itu menyebabkan keseimbangan kontrol antara beberapa aktor dan ini menghasilkan keseimbangan dalam masyarakat. Keseimbangan terlihat pada adanya pembentukan kelompok pemuda tani hortikultura yang memiliki tujuan selain sebagai wadah bagi pemuda tani namun juga sebagai upaya untuk mengatasi kendala atau keterbatasan yang dimiliki aktor individu.

Pada kelompok tani Mudo Mulyo Dadi, keterbatasan aktor individu terhadap akses sumberdaya lahan dimaksimalkan dengan melakukan sistem pengoptimalan penanaman sehingga dengan keterbatasan lahan aktor individual tetap dapat meraih tujuannya. Pada prilaku kolektif memiliki aktor-aktor kolektif yang memiliki akses lebih banyak terhadap sumberdaya modal yaitu teknologi dan informasi. Pada kelompok pemuda tani Mudo Mulyo Dadi, akses terhadap teknologi mendapatkan bantuan pemerintah berupa alat cultivator dan mesin tepung cabai yang tentunya menunjang produktifitas aktor-aktor individu maupun kolektif untuk meraih tujuan-tujuannya.

Proses terbentuknya pilihan rasional dalam penelitian ini yaitu ketika pemuda desa memutuskan untuk melakukan kegiatan pertanian hortikultura sebagai mata pencaharian utamanya dengan tujuan untuk melakukan kegiatan yang lebih positif, memenuhi kebutuhan 
keluarga dan meningkatkan taraf hidup. Lahan merupakan salah satu sumber daya alam yang dimiliki pemuda untuk meraih tujuannya namun selain itu juga terdapat sumberdaya modal yang dimiliki pemuda sebagai aktor individu dalam mendapatkan tujuannya. Aktor individu tidak dapat selamanya mengemban kepentingan mereka sendiri maka dari itu aktor individu dalam upayanya memaksimalkan kepentingkan mereka akan melakukan prilaku kolektif yang menyebabkan adanya keseimbangan kontrol antara beberapa aktor dan dapat menghasilkan keseimbangan dalam masyarakat.

\section{KESIMPULAN}

Dalam banyaknya kasus mengenai rendahnya minat pemuda dalam sektor pertanian, terdapat kelompok pemuda di Desa Kelor, Kecamatan Karangmojo, Kabupaten Gunungkidul yang memiliki minat terhadap sektor pertanian dan sedang mengembangkan pertanian hortikultura adanya meningkatnya minat pemuda pada pertanian hortikultura, diharapkan mampu menimbulkan dampak positif pada pemuda-pemuda lainnya untuk tidak lagi memandang sektor pertanian sebagai sektor yang tidak menguntungkan. Munculnya minat pemuda terhadap pertanian merupakan suatu bentuk pilihan rasional yang juga merupakan tindakan rasional dari seorang individu ataupun aktor untuk melakukan suatu tindakan berdasarkan tujuan tertentu dan tujuan tersebut ditentukan oleh nilai atu prefernsi (pilihan) seperti yang dijabarkan Coleman pada teori pilihan rasional. Aktor dalam proses meningkatnya minat pemuda terhadap pertanian di Desa Kelor dipandang sebagai seorang individu yang dalam tindakannya memiliki suatu tujuan tertentu. Dari hasil penelitian peningkatan minat pemuda dalam pertanian dilihat dari adanya peningkatan keterlibatan pemuda, penigkatan anggota kelompok pertanian, peningkatan jumlah lahan pertanian dan peningkatan inovasi pertanian. Pada keterlibatan pemuda dalam pertanian yang dibedakan menjadi keterlibatan langsung dan penunjang dengan memperhatikan frekuensi, lama bertani dan luasan lahan yang dimiliki pemuda dalam melakukan kegiatan pertaniannya.

Dalam penelitian ini sejalan dengan pemikiran James S. Coleman tentang pilihan rasional. Aktor dalam hal ini dapat berbentuk kelompok atau individu. Meskipun teori pilihan rasional berangkat dari tujuan atau maksud aktor, tetapi pada teori ini memiliki pandangan terhadap dua pembatas utama pada tindakan itu. Pertama adalah keterbatasan sumber daya, bagi aktor yang mempunyai sumber daya besar, maka pencapaian tujuan cenderung lebih mudah. Akan tetapi bagi aktor yang memiliki sedikit sumber daya, jika memang ada, pencapaian tujuan mungkin sulit atau mustahil (Ritzer, 2012). Hal tersebut juga terjadi pada pemuda yang tergabung dalam pemuda tani hortikultura Mudo Mulyo Dadi, bagi pemuda yang memiliki akses terhadap sumber daya diantaranya lahan dan modal menjadi lebih mudah untuk menggapai tujuan yang diimpikannya saat memilih untuk terjun pada sektor pertanian. Sedangkan pada aktor yang disini merupakan pemuda dengan keterbatasan akses terhadap sumberdaya lahan dan modal disisi lain akan sedikit lebih lambat dalam menggapai tujuannya. Pada saat aktor individual mementingkan tujuan pribadinya, muncul aktor korporat yang dalam kolektivitas seperti itu, aktor tak boleh bertindak menurut kepentingan pribadi mereka, tetapi harus bertindak menurut kepentingan kolektivitas atau kelompok. Adanya peranan aktor korporat membantu menyelesaikan masalah mengenai keterbatasan skses sumber daya oleh anggota kelompok pemuda tani Mudo Mulyo Dadi dengan melakukan berbagai macam ekperimen untuk mendapatkan hasil yang maksimal yaitu dengan memaksimalkan penanaman pada lahan sempit dengan memberikan jarak pada masing-masing tanaman agar tanaman dapat tumbuh lebat dan memudahkan proses penyemprotan hama. Sehingga permasalahan keterbatasan akses sumberdaya tertutupi oleh pemikiran-pemikiran yang dihasilkan oleh aktor korporat untuk kepentingan kolektif. 


\section{DAFTAR PUSTAKA}

Ahmadi dan Irsal. 2006. Inovasi teknologi pengembangan pertanian lahan rawa lebak. Prosiding Seminar Nasional "Pengembangan Pertanian". Banjarbaru: Balai Penelitian Pertanian Lahan Rawa.

Apriyanto A. (2012). Pembangunan Pertanian di Indonesia. Dipetik Desember, 30, 2019. Dari http://www.deptan.go.id/renbangtan/konsep_pembangunan_pertanian.pdf.

Direktorat Jendral Hortikultura. Rencana Strategis Direktorat Jendral Hortikultura 20152019. Dipetik Juli, 29, 2019. Dari http://hortikultura.pertanian.go.id/wpcontent/uploads/2015/06/Bab-II.pdf

Djaali. (2008). Psikologi Pendidikan. Jakarta: Bumi Aksara.

Hadi, P.U., Mayrowani, H. Supriyati dan Sumedi. 2000. Review and Outlook Pengembangan Komoditas Hortikultura. Seminar Nasional Perspektif Pembangunan Pertanian dan Kehutanan Tahun 2001 ke Depan. Pusat Penelitian Sosial Ekonomi Pertanian. Bogor: Badan Penelitian dan Pengembangan Pertanian.

Istiqomah, Kurnia. (2017). Hubungan Persepsi dengan Sikap Pemuda Pedesaan Mengenai Pekerjaan Pertanian Hortikultura (Desa Ciputri Kecamatan Pacet Kabupaten Cianjur Jawa Barat). Skripsi Institut Pertanian Bogor. Dipetik April, 11 ,2019. Dari https://repository.ipb.ac.id/jspui/handle/123456789/93/browse?type=title\&sort_by=1 \&order $=$ ASC \&rpp $=60 \&$ etal $=5 \&$ null $=\&$ offset $=459$

Kementrian Pertanian. Peraturan Menteri Pertanian Nomor 82/Permentan/OT.140/8/2013. Dipetik Juli, 30, $2019 . \quad$ Dari http://perundangan.pertanian.go.id/admin/p_mentan/Permentan\%20No.82\%20T ahun\%202013.pdf

Mardikanto, Totok. (2007). Penyuluhan Pembangunan Pertanian. Surakarta: UNS Press.

Mukhlis, 2007. Analisis Tanah Dan Tanaman. Medan: USU Press.

Musyafak ahmad dan Tatang M.Ibrahim, 2005. Strategi Percepatan Adopsi dan Difusi Teknologi Pertanian dalam Prima Tani. Journal Analisis kebijakan Pertanian, Vol.1.No.1, Maret 2005.

Nugraha YA. (2012). Hubungan orangtua, media massa, dan teman dengan sikap pemuda terhadap pekerjaan di bidang pertanian (kasus pemuda di Cipendawa dan Sukatani, Kecamatan Pacet Kabupaten Cianjur). Bogor: Institut Pertanian Bogor.

Prastowo B. (2007). Potensi Sektor Pertanian Sebagai Penghasil dan Pengguna Energi Terbarukan. Jurnal Perspektif Vol. 6 No. 2. Dipetik Januari, 10, 2019. Dari http://ejurnal.litbang.pertanian.go.id/index.php/psp/article/view/2862/2489.

Suhartini, Yati. (2011). Analisis Faktor-Faktor Yang Mempengaruhi Minat Mahasiswa dalam Berwiraswasta. Jurnal Akmenika UPY, Vol. 7.

Untari et al. (2007). Implementasi Prinsip-Prinsip Pertanian Berkelanjutan oleh Petani di Kabupaten Kulon Progo. Ilmu-ilmu Pertanian 3(2): 144-155. Dipetik Maret, 2, 2019 dari http://stppyogyakarta.com.

White B. (2011). Who will own the countryside dispossession, rural youth and the future of farming. International Institute of Social Studies. Dipetik Maret, 18, 2019 dari http://pustaka.setjen.pertanian.go.id/.

(2012). Agriculture and the Generation Problem: Rural Youth, Employment and the Future of Farming. Journal IDS Bulletin Volume 43 Number 6. Dipetik Januari, 10, 2019 dari https://core.ac.uk/download/pdf/43538583.pdf

Wiradi, Gunawan. (2009). Metodologi Studi Agraria. Bogor: Sajogyo Institute. 